\title{
Prevalence of dermatologic disorders in 15 patients with acromegaly
}

\author{
Prevalência de alterações dermatológicas em 15 pacientes acromegálicos
}

\author{
Mariângela Resende ${ }^{1}$ \\ Vânia dos Santos Nunes ${ }^{3}$
}

\author{
Fernanda Bolfi ${ }^{2}$ \\ Hélio Amante Miot ${ }^{4}$
}

\begin{abstract}
Acromegaly is a chronic, insidious and rare disease, caused by hyper secretion of the growth hormone, which metabolic and trophic effects commonly result in cutaneous manifestations, sometimes preceding other clinical symptoms. The authors have assessed 15 patients with acromegaly and found dermatologic lesions in all of them, mainly skin thickening, acrochordons, epidermoid cysts, pseudoacanthosis nigricans, seborrheic keratosis, melanocytic naevi and lentiginous spots.
\end{abstract}

Keywords: Acanthosis nigricans; Acromegaly; Adenoma; Growth hormone; Skin manifestations

Resumo: Acromegalia é doença crônica rara, insidiosa, decorrente da hipersecreção de hormônio do crescimento, cujos efeitos tróficos e metabólicos frequentemente incorrem em manifestações cutâneas, que podem ser precoces. Os autores avaliaram 15 pacientes portadores de acromegalia e evidenciaram alterações dermatológicas em todos, principalmente espessamento da pele, acrocórdons, cistos epidérmicos, pseudoacantose nigricante, queratoses seborreicas, nevos melanocíticos e manchas lentiginosas. Palavras-chave: Acantose nigricans; Acromegalia; Adenoma; Hormônio do crescimento; Manifestações cutâneas

Acromegaly is a chronic disease caused by the hyperplasia of the pituitary mesenquimal tissue and excessive secretion of growth hormone $(\mathrm{GH})$ by the adenohypophysis. It is rare, developing in around 4070 cases per million people. It develops mostly in adults between 30 and 50 years, with no predilection for gender. It has an insidious progress and early dermatological manifestations. ${ }^{1-3}$

The endocrine manifestations caused by the excess of the GH are mediated by somatomedines, especially by the insulin-simile growth factor (IGF-1). More than $95 \%$ of the cases are sporadic and secondary to hypophisary adenomas.

Raised levels of GH lead to connective tissue, bone, skin and skin annexes hyperplasia, with possible collagen thickening and interstitial liquid retention, causing early growth of the extremities (hands, feet, fingers and toes) and, subsequently, of the facial bones. Some cases might be associated with multiple endocrine neoplasia type 1, McCune-Albright syndrome and Carney complex. ${ }^{1}$

Acromegalic patients have a higher chance of developing benign and malignant neoplasias, from the breast, gastrointestinal tract, thyroid and skin. ${ }^{1,3,4}$

Cutaneous findings are described in acromegaly, such as: skin thickening with bulging folds and evidenced sulcus, increased eccrine, apocrine and sebaceous secretions, acrochordons, lentigine spots, blue

Received on 24.11.2010.

Approved by the Advisory Board and accepted for publication on 27.12.10.

* Work performed at the Dermatology and Radiology Department of the Medical School of Botucatu - Universidade Estadual Paulista "Julio de Mesquita Filho" (UNESP) - Botucatu (SP), Brasil.

Conflict of interest: None / Conflito de interesse: Nenhum

Financial funding: None / Suporte financeiro: Nenbum

Physician - Resident in dermatology at the Dermatology and Radiology Department of the Universidade Estadual Paulista "Julio de Mesquita Filho" (UNESP) - Botucatu (SP), Brasil.

Physician - Resident in endocrinology at the Internal Medicine Department of the Universidade Estadual Paulista "Julio de Mesquita Filho" (UNESP) - Botucatu (SP), Brasil.

PhD - Substitute Professor of Endocrinology at the Internal Medicine Department of the Universidade Estadual Paulista "Julio de Mesquita Filho" (UNESP) Botucatu (SP), Brasil.

PhD - Assistant Professor at the Dermatology and Radiology Department of the Universidade Estadual Paulista "Julio de Mesquita Filho" (UNESP) - Botucatu (SP), Brasil. 
nevi, mucocutaneous mixomas, psammomatous melanotic schwannomas, pseudoacanthosis nigricans, hypertrichosis, macronychia, koilonychia, Beau lines, seborrheic keratosis, lipomas, epidermic cysts and melanotic abnormalities. ${ }^{2,5-7}$

Due to the rarity of the disease, publications of case series that describe the dermatological manifestations are uncommon. In this study the authors aim to describe the prevalence of dermatological manifestations in acromegalic patients and compare their results with those from the literature.

In order to assess the frequency of cutaneous findings in acromegalic patients in university services a cross-sectional study was performed, where 15 patients seen at the Endocrinology outpatients clinic of the Faculdade de Medicina de Botucatu - UNESP were interviewed and submitted to a complete dermatological examination. The prevalence of the dermatosis studied was represented by their percentages and a confidence interval of $95 \%$.

The age of the patients varied between 33 and 65 years, an average of 53 years (standard deviation of 10 years), and $73 \%$ of them were female. The average body mass index was $27 \mathrm{~kg} / \mathrm{m}^{2}$ (standard-deviation of $5 \mathrm{~kg} / \mathrm{m}^{2}$ ), and $67 \%$ of the participants were overweight. There was a predominance of the phototype III (46\%), followed by phototype V (27\%) and III (20\%).

All patients presented with cutaneous abnormalities and the main ones on this sample and on the literature are described on table 1 . The cutaneous thickening, acrochordons, epidermic cysts, seborrheic keratosis, melanocytic nevi and lentiginous spots stand out.

The abnormalities found in acromegalic patients are caused by chronic exposure of the tissues to excessive amounts of GH e IGF-1, due to their trophic and metabolic effects. The histopathological exam of the skin shows deposits of glycosaminoglicans, usually hyaluronic acid and condroitin sulphate, on the reticular dermis, which causes liquid retention. ${ }^{6}$ The hyper pigmentation is associated with higher levels of the melanotrophic hormone. ${ }^{2}$ Hirsutism, pore dilation and sebaceous hyper secretion are caused by the higher proportion of free testosterone due to the decrease of the testosterone transporting protein, as well as the direct effect of the GH on the follicles. $^{1,2,5}$

Cutaneous thickening is described as highly prevalent among the acromegalics, affecting the face, hands, palms, soles and heels. Eventually a digital papulosis can be identified, especially when associated with insulin resistance, which can develop in up to $50 \%$ of the cases. ${ }^{1,3}$

IGF-1 receptors are found on the keratinocytes and fibroblasts and induce their hyperplasia, which could explain the high prevalence of cutaneous thickening, pseudoacanthosis nigricans and acrochordons seen in these patients. ${ }^{1,8}$

The significative occurrence of epidermic cysts and lentiginous spots in these patients are not highlighted on the literature and due to their high frequency on the normal adult population, comparative studies are necessary in order to confirm their associa-

TABLE 1: Prevalence of dermatologic findings in the patients with acromegaly

\begin{tabular}{|c|c|c|c|c|c|}
\hline & $\begin{array}{l}\text { Billon, } 1996^{\circ} \\
\text { N (\%) }\end{array}$ & $\begin{array}{l}\text { Arya, } 1997^{10} \\
\text { N (\%) }\end{array}$ & $\begin{array}{l}\text { Dahbar, } 2009^{7} \\
\text { N }(\%)\end{array}$ & $\begin{array}{l}\text { Presente estudo } \\
\text { N (\%) }\end{array}$ & $\begin{array}{l}\text { Total } \\
\text { N (\%) }\end{array}$ \\
\hline $\begin{array}{l}\text { Skin thickening } \\
\text { (face, hands and feet) }\end{array}$ & $4(100)$ & $34(100)$ & $19(100)$ & $15(100)$ & $72(100)$ \\
\hline Acrochordons & $1(25)$ & $2(6)$ & $8(42)$ & $11(73)$ & $22(31)$ \\
\hline Epidermic cysts & NA & NA & NA & $8(53)$ & $8(53)$ \\
\hline Pseudoacanthosis nigricans & NA & $3(9)$ & $2(11)$ & $8(53)$ & $13(19)$ \\
\hline Lentiginous spots & $1(25)$ & NA & NA & $8(53)$ & $9(47)$ \\
\hline Hirsutism / Hypertrichosis & $\mathrm{NA}$ & $4(27 *)$ & $1(5)$ & $2(13)$ & $7(14)$ \\
\hline Hyperidrosis & NA & $11(32)$ & $7(37)$ & - & $18(27)$ \\
\hline Acne & NA & NA & $2(11)$ & $2(13)$ & $4(12)$ \\
\hline Oily skin & $1(25)$ & NA & $15(79)$ & NA & $16(70)$ \\
\hline Macroglossy & $1(25)$ & NA & $4(21)$ & - & $5(13)$ \\
\hline Onychodystrophy & NA & NA & $6(32)$ & - & $6(8)$ \\
\hline Seborrheic keratosis & $1(25 * *)$ & NA & $1(5 * *)$ & $6(40)$ & $8(21)$ \\
\hline Digital papilosis & NA & NA & NA & $3(20)$ & $3(20)$ \\
\hline Lipomas & NA & NA & NA & $2(13)$ & $2(13)$ \\
\hline Melanocytic nevi & $1(25)$ & NA & NA & & \\
\hline
\end{tabular}

* Among women ** Eruptive form, NA: Not assessed 
tion with acromegaly. However, we did not find onychodystrophy, hyper pigmentation and hypertrichosis, described in a considerable number of patients. ${ }^{7,9,10}$

We also observed the occasional presence of melasma (27\% of the women), psoriasis (7\%), hidradenitis suppurativa (7\%), sebaceous hyperplasia (7\%), Civatte poikiloderma (7\%), xanthelasma (7\%) and vascular lesions like cherry angiomas (13\%) and facial telangiectasia (7\%). However, we did not see blue nevi, cutis verticis gyrata, mucocutaneous mixomas or psammomatous melanotic schwannomas.

Acne was evidenced in our cases in a percentage very similar to other studies, although in a prevalence below the expected due to the high frequency of oily skin among the patients. ${ }^{5,7,10}$

One of the earliest signs of acromegaly is the oedematous and pasty sensation described by the patients and the hyperidrosis, considered as a marker of disease activity. With adequate treatment and control of the GH synthesis it is possible that the cuta- neous findings decrease or remain unaltered. ${ }^{1,5}$

As all the patients in this study were already under treatment, the prevalence of the cutaneous abnormalities according to the levels of $\mathrm{GH}$ or the insulin resistance could not be assessed.

The progression of the disease tends to be slow and insidious and this is the main reason for the late diagnosis, around 8 to 10 years after the development of the first signs and symptoms. This fact is extremely relevant, because acromegalic patients have a mortality rate $2-4$ times higher than the general population of the same age and sex, and the early diagnosis can prevent cardiovascular, respiratory and neoplastic complications, the main causes of the higher mortality in these individuals. ${ }^{3}$

Cutaneous alterations are common in acromegaly and dermatologists can be seen before the patients note the dysmorphic signs of the disease, when they have the opportunity to suspect the diagnosis and initiate early treatment.

\section{REFERENCES}

1. Ben-Shlomo A, Melmed S. Skin manifestations in acromegaly. Clin Dermatol. 2006;24:256-9

2. Zanini M, Oshiro R, Paschoal L, Paschoal F, Timoner F. Aspectos dermatológicos da acromegalia. An Bras Dermatol. 2004;79:491-4

3. Chanson P, Salenave S. Acromegaly. Orphanet J Rare Dis. 2008;3:17.

4. Baris D, Gridley G, Ron E, Weiderpass E, Mellemkjaer L, Ekbom A, et al. Acromegaly and cancer risk: a cohort study in Sweden and Denmark. Cancer Causes Control. 2002;13:395-400.

5. Centurion SA, Schwartz RA. Cutaneous signs of acromegaly. Int J Dermatol. 2002:41:631-4.

6. Thiboutot DM. Clinical review 74: Dermatological manifestations of endocrine disorders. J Clin Endocrinol Metab 1995:80:3082-7.

7. Dahbar M, Danilowicz K, Malavela M, Velásquez D, Allevato M, Cabrera H, et al. Manifestaciones cutáneas en la acromegalia. Dermatol Argent. 2009;15:186-90.

8. Tamega Ade A, Aranha AM, Guiotoku MM, Miot LD, Miot HA. Associação entre acrocórdons e resistência à insulina. An Bras Dermatol. 2010;85:25-31.

9. Billon C, Beylot-Barry M, Doutre MS, Latapie JL, Roger P, Beylot C. Cutaneous manifestations of acromegaly: 4 cases. Ann Dermatol Venereol. 1996;123:821-3.

10. Arya KR, Krishna K, Chadda M. Skin manifestations of acromegaly - a study of 34 cases. Indian J Dermatol Venereol Leprol 1997;63:178-80.

\author{
MAILING ADDRESS / ENDEREÇO PARA CORRESPONDÊNCIA : \\ Prof. Hélio Amante Miot \\ Departamento de Dermatologia da Faculdade de \\ Medicina da Unesp, $S / N$. \\ Campus Universitário de Rubião Jr. \\ 18618-000 Botucatu, SP, Brazil \\ Phone/fax: +55 (14) 3882-4922 \\ E-mail: beliomiot@fmb.unesp.br
}

How to cite this article/Como citar este artigo: Resende M, Bolfi F, Nunes VS, Miot HA. Prevalence of dermatologic disorders in 15 patients with acromegaly. An Bras Dermatol. 2012;87(1):166-8. 